\title{
cDNA sequencing improves the detection of P53 missense mutations in colorectal cancer
}

\author{
Malgorzata Szybka*†1, Magdalena Zakrzewska ${ }^{\dagger 2}$, Piotr Rieske², Grazyna Pasz- \\ Walczak $^{1}$, Dominika Kulczycka-Wojdala1, Izabela Zawlik², Robert Stawski², \\ Dorota Jesionek-Kupnicka1 ${ }^{1}$, Pawel P Liberski ${ }^{2}$ and Radzislaw Kordek ${ }^{1}$
}

\author{
Address: ${ }^{1}$ Department of Oncological Pathology, Chair of Oncology, Medical University of Lodz, Poland, Paderewskiego 4, 93-509 Lodz, Poland \\ and ${ }^{2}$ Department of Molecular Pathology and Neuropathology, Chair of Oncology, Medical University of Lodz, Poland \\ Email: Malgorzata Szybka* - mszybka@wp.pl; Magdalena Zakrzewska - madziazakrzewska@wp.pl; Piotr Rieske - piotrrieske@yahoo.com; \\ Grazyna Pasz-Walczak - grazyna.walczak@synevo.pl; Dominika Kulczycka-Wojdala - domwoj@wp.pl; Izabela Zawlik - izazawlik@yahoo.com; \\ Robert Stawski - stawu@op.pl; Dorota Jesionek-Kupnicka - kupidor@poczta.onet.pl; Pawel P Liberski - ppliber@csk.umed.lodz.pl; \\ Radzislaw Kordek - rkordek@csk.am.lodz.pl \\ * Corresponding author †Equal contributors
}

Published: II August 2009

BMC Cancer 2009, 9:278 doi:10.1 |86/| 47|-2407-9-278

This article is available from: http://www.biomedcentral.com//47I-2407/9/278

(c) 2009 Szybka et al; licensee BioMed Central Ltd.

This is an Open Access article distributed under the terms of the Creative Commons Attribution License (http://creativecommons.org/licenses/by/2.0), which permits unrestricted use, distribution, and reproduction in any medium, provided the original work is properly cited.
Received: 15 October 2008

Accepted: II August 2009

\begin{abstract}
Background: Recently published data showed discrepancies beteween P53 cDNA and DNA sequencing in glioblastomas. We hypothesised that similar discrepancies may be observed in other human cancers.

Methods: To this end, we analyzed 23 colorectal cancers for P53 mutations and gene expression using both DNA and cDNA sequencing, real-time PCR and immunohistochemistry.

Results: We found P53 gene mutations in 16 cases ( 15 missense and I nonsense). Two of the 15 cases with missense mutations showed alterations based only on CDNA, and not DNA sequencing. Moreover, in 6 of the 15 cases with a cDNA mutation those mutations were difficult to detect in the DNA sequencing, so the results of DNA analysis alone could be misinterpreted if the cDNA sequencing results had not also been available. In all those 15 cases, we observed a higher ratio of the mutated to the wild type template by cDNA analysis, but not by the DNA analysis. Interestingly, a similar overexpression of $P 53$ mRNA was present in samples with and without P53 mutations.
\end{abstract}

Conclusion: In terms of colorectal cancer, those discrepancies might be explained under three conditions: I, overexpression of mutated P53 mRNA in cancer cells as compared with normal cells; 2 , a higher content of cells without P53 mutation (normal cells and cells showing K-RAS and/or APC but not P53 mutation) in samples presenting P53 mutation; 3, heterozygous or hemizygous mutations of P53 gene. Additionally, for heterozygous mutations unknown mechanism(s) causing selective overproduction of mutated allele should also be considered. Our data offer new clues for studying discrepancy in P53 cDNA and DNA sequencing analysis. 


\section{Background}

In a recently published study, we showed the prevalence of the mutated P53 template by cDNA sequencing and determination of the wild type template by DNA analysis in glioblastomas (GBM). That investigation allowed us to propose three plausible hypotheses to explain those discrepancies: 1 , the silencing of wild type mRNA transcription; 2, the degradation of wild type mRNA; 3 , the selective overproduction of mutated mRNA [1]. We decided to test if similar discrepancies occur in other human cancers. For this study, colorectal cancer (CC) was selected as a common cancer presenting frequent P53 mutations.

The P53 gene status was evaluated by means of both cDNA and DNA sequencing, real-time RT-PCR and immunohistochemistry. This comprehensive approach allowed us to go toward an explanation of divergent results observed following cDNA and DNA P53 sequencing. Our investigation also sheds new light on the discrepancies between immunohistochemical and molecular analyses of $P 53$ in CC.

\section{Methods}

\section{Tumor samples}

Resected specimens from 23 patients with colorectal cancer who underwent resection in the Clinical Department of Surgical Oncology, Chair of Oncology, Medical University of Lodz between January 1998 and December 2001 were studied.

Immediately after surgery specimens for molecular study were taken from resected tumors and placed in liquid nitrogen, and next stored in $-80^{\circ} \mathrm{C}$. The rest of resected material was routinely fixed in $10 \%$ buffered formalin. After 24 hour fixation specimens taken from tumors were dehydrated through graded alcohols and acetones, cleared in xylenes and embedded in paraffin blocks at $56^{\circ} \mathrm{C}$. For histopatological diagnosis sections $4 \mu \mathrm{m}$ thick of formaline-fixed, paraffin embedded tissue were placed on polyL lysine coated slides and stained with hematoxylin and eosin. All tumors were diagnosed at Department of Tumor Pathology, Chair of Oncology, Medical University of Lodz according to the WHO criteria.

All analyses were performed on archival material with the approval of the Bioethics Medical University Committee No. RNN/53/08/KE.

\section{DNA and RNA isolation}

All analyses were performed using snap-frozen tissues stored at $-80^{\circ} \mathrm{C}$. DNA and RNA were co-extracted by means of Macherey-Nagel DNA/RNA purification kit from normal and tumor tissues. RNA samples were treated with DNase. RNA and DNA concentrations were measured spectrophotometrically. 100 ng of total RNA was reverse-transcribed into single-stranded cDNA in a final volume of $40 \mu \mathrm{l}$ containing $50 \mathrm{mM}$ DTT, $1.5 \mu \mathrm{g}$ oligo(dT), $0.5 \mathrm{mM}$ dNTP, 40 units of RNase inhibitor and 200 units of M-MLV reverse transcriptase (Promega).

\section{DNA and CDNA sequencing}

Exons 5-8 of the P53 gene were amplified by PCR as described before and sequenced using the dideoxy termination method and SequiTherm Excel DNA Sequencing Kit (Epicentre Technologies) [1,2]. To verify the results of sequencing the semi-quantitative densitometric analysis was performed. The intensity of wild type and mutated bands was estimated comparing to the neighbouring bands in the same sequencing lane used as a reference.

\section{Estimation of sequencing sensitivity}

DNA samples consisting of either wild type or mutated templates were obtained from control samples and specimens containing only mutated bands respectively. Moreover, a DNA sample obtained from patient with LiFraumeni syndrome (that we previously reported) was used as an example of a $50 \%$ presence of the mutated template [3]. Samples presenting only a mutated band (A) and $50 \%$ presence of the mutated template (B) were mixed with control samples (C) in the following proportions expressed in percent, respectively: $100 / 0 ; 87,5 / 12,5$; $75 / 25 ; 50 / 50 ; 25 / 75 ; 12,5 / 87,5 ; 0 / 100$ for $\mathrm{A} / \mathrm{C}$ and $50 / 50$; $40 / 60 ; 33,3 / 66,6 ; 25 / 75 ; 12,5 / 87,5 ; 0 / 100$ for B/C.

\section{Immunohistochemistry}

Sections $4 \mu \mathrm{m}$ thick of formaline-fixed, paraffin embedded tissue were placed on SuperFrost Plus slides (MenzelGlaser, Braunschweig, Germany). These were deparaffinized in xylenes and rehydrated through graded alcohols. Then, the sections were microwaved in $0.01 \mathrm{M}$ sodium citrate buffer, $\mathrm{pH} 6.0$, twice for 10 minutes at $360 \mathrm{~W}$ to epitope retrieval. After the slides were rinsed in running water, washed with TRIS buffered saline, $\mathrm{pH} 7.4$, and incubated for 1 hour at room temperature with the primary monoclonal antibody anti-P53 (clone DO-7, 1:100 dilution, DAKO, Glostrup, Denmark), and processed with EnVision (DAKO, Glostrup, Denmark) system. Sections were counterstained with haematoxylin, dehydrated with ethanol and cleared in xylene. For all tumors P53 labelling indices defined as the percentage of positive nuclei, were determined by counting 1000 cells in high power fields $(\times 400)$. The slides were scored by two independent pathologists. When regional heterogenity of labelling was detected in the tumor, counting areas were chosen to include those with the most pronounced staining.

\section{Real-time quantitative RT-PCR}

Real-time quantitative RT-PCR was performed on a Rotor Gene 6000 instrument (Corbett, Life Sciences, Australia) 
for P53 gene (TaqMan ${ }^{\circledR}$ Gene Expression Assays no. Hs00153340_m1 and Hs00153349_m1) with GAPDH (TaqMan ${ }^{\circledR}$ Gene Expression Assays no. Hs99999905_m1) used as a reference gene for normalization of the target genes expression levels. A normalized relative expression level for a given target gene in unknown sample versus control sample was calculated using the method described previously by Pfaffl et al. with pooled cDNA from all tumor samples used as a control, according to the equation:

$$
\text { Ratio }=\frac{\left(E_{\text {TARGET }}\right)^{\Delta C P_{\text {TARGET }}(\text { control-sample })}}{\left(E_{R E F}\right)^{\Delta C P_{R E F}(\text { control-sample })}}
$$

where $\mathrm{E}_{\text {TARGET }}$ and $\mathrm{E}_{\mathrm{REF}}$ stand for the real-time PCR efficiency of target and reference gene amplification, respectively, and $\Delta \mathrm{CP}_{\mathrm{TARGET}}$ (control-sample) and $\Delta \mathrm{CP}_{\mathrm{REF}}$ (control-sample) denote the difference in crossing points (CP) between unknown and control samples for a given target and reference genes, respectively [4].

\section{Statistical analysis}

The differences in gene expression levels were evaluated by Mann-Whitney $U$ test. Statistical significance was assumed for $P$-value $\leq 0.05$.

\section{Loss of heterozygosity (LOH) and microsatellite instability (MSI) analyses}

Analyses were performed using paired tumor specimens and control tissues to recognize hemizygous mutations of P53 gene by using the following microsatellite markers: D17S976, D17S675, D17S1828 and D17S729. Forward primers were 5 ' end fluorescence-labelled. PCR was performed in thermocycling conditions established individually for each pair of primers. The percentage of nontumor cells contaminating analyzed specimens was estimated based on LOH and MSI analysis as was already described [5].

\section{Results}

Sequencing of cDNA shows mutation more frequently than sequencing of DNA

Sequencing of cDNA showed P53 missense mutations in 15 specimens and nonsense mutation in one case of 23 analyzed CC. DNA sequencing performed for 15 samples with missense mutation detected P53 gene mutation only in six samples, in another six cases, the mutated template was difficult to detect, in the final two cases the DNA analyses did not revealed a P53 gene alteration (for one sample DNA was not analyzed). In all cases with a P53 mutation, the increased ratio of mutated to wild type tem-
A

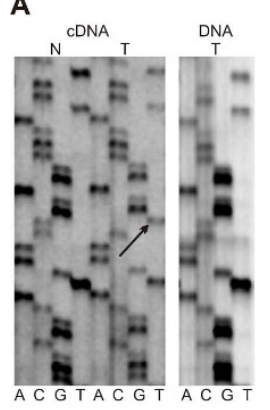

B

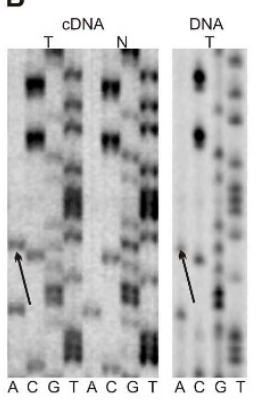

D

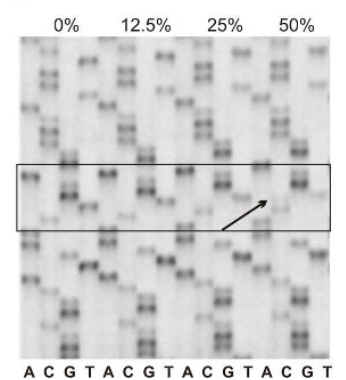

Figure I

Molecular analyses of P53 gene. (A) cDNA sequencing showing mutation (arrow) and DNA analysis confirming presence of wild type nucleotide only (case no. 3 in Table I). (B) cDNA and DNA sequencing showing both bands equally (case no. I in Table I). (C) cDNA sequencing showing prelevance of mutated nucleotide, and DNA presenting prelevance of wild type band (case no. 9 in Table I). (D) estimation of sequencing sensitivity for sample presenting only mutated band, see Materials and Methods (case no. 3 in Table I). (E) example of $\mathrm{LOH}$ analysis for microsatellite marker DI7S675. The lost allele is marked with an arrow (case no. I3, left and I0, right in Table I). LOH analysis confirms a high amount of nontumor cells (cells without LOH on I7 p) in sample no. I3. N, normal tissue (blood); T, tumor sample.

plate was observed after cDNA analyses, when compared with DNA analyses (Figure 1, Table 1).

\section{LOH analysis suggests presence of hemizygous $P 53$ mutations and a high contamination of nontumor cells}

Eleven of the 16 CC cases containing P53 mutations also showed a loss of heterozygosity on chromosome $17 \mathrm{p}$ (Table 2). Two samples with a clear gene mutation, confirmed on the basis of the cDNA sequencing, but not following the DNA analysis, showed also LOH on $17 \mathrm{p}$, which attests to the presence of P53 hemizygous mutations. LOH analyses confirmed presence of cells without LOH at $17 \mathrm{p}$ in analyzed specimens (Figure 1). The content of such cells (nontumor cells) is shown in Table 1. 
Table I: Results of molecular and immunohistochemical analyses of P53 gene.

\begin{tabular}{|c|c|c|c|c|c|c|c|c|c|}
\hline No & $17 \mathrm{p}$ & Mutation & Exon & Codon & Effect & cDNA & DNA & Cells without LOH I7 p & $\begin{array}{l}\text { Normalized relative expres- } \\
\text { sion level of P53 mRNA }\end{array}$ \\
\hline I & $\mathrm{LOH}$ & $\mathrm{CGT}>\mathrm{CAT}$ & 8 & 273 & $\mathrm{Arg} \rightarrow \mathrm{His}$ & $\mathrm{WT}=\mathrm{MT}$ & $\mathrm{WT}=\mathrm{MT}$ & $25-35 \%$ & 3,201 \\
\hline 2 & $\mathrm{LOH}$ & GTG>ATG & 5 & 173 & $\mathrm{Val} \rightarrow \mathrm{Met}$ & only MT & $\mathrm{MT}>\mathrm{WT}$ & $15-25 \%$ & 2,934 \\
\hline 3 & $\mathrm{LOH}$ & CGG>TGG & 7 & 248 & Arg $\rightarrow$ Trp & only MT & WT & $50-60 \%$ & 3,796 \\
\hline 4 & $\mathrm{LOH}$ & $\mathrm{CGC}>\mathrm{CAC}$ & 5 & 175 & $\mathrm{Arg} \rightarrow \mathrm{His}$ & only MT & $\mathrm{WT}=\mathrm{MT}$ & $25-35 \%$ & 4,235 \\
\hline 5 & $\mathrm{LOH}$ & CGT>CAT & 8 & 273 & $\mathrm{Arg} \rightarrow \mathrm{His}$ & $M T>W T$ & $\mathrm{WT}=\mathrm{MT}$ & $25-35 \%$ & 3,497 \\
\hline 6 & $\mathrm{LOH}$ & $\mathrm{GAG}>\mathrm{AAG}$ & 8 & 285 & Glu $\rightarrow$ Lys & $M T>W T$ & WT & $40-50 \%$ & 4,443 \\
\hline 7 & $U$ & GGC>AGC & 7 & 245 & Gly $\rightarrow$ Ser & only MT & WT $>M T$ & - & 3,005 \\
\hline 8 & $\mathrm{ROH}$ & $\mathrm{CGG}>\mathrm{CAG}$ & 7 & 248 & $\mathrm{Arg} \rightarrow \mathrm{Gln}$ & only MT & $\mathrm{WT}>\mathrm{MT}$ & - & 3,928 \\
\hline 9 & $\mathrm{ROH}$ & $\mathrm{CGT}>\mathrm{CAT}$ & 8 & 273 & $\mathrm{Arg} \rightarrow \mathrm{His}$ & $M T>W T$ & $\mathrm{WT}>\mathrm{MT}$ & - & 1,692 \\
\hline 10 & $\mathrm{LOH}$ & CGG>TGG & 8 & 282 & Arg $\rightarrow$ Trp & only MT & $\mathrm{WT}>\mathrm{MT}$ & $25-35 \%$ & 3,307 \\
\hline II & $\mathrm{ROH}$ & GGC>AGC & 7 & 245 & Gly $\rightarrow$ Ser & $\mathrm{MT}=\mathrm{WT}$ & WT $>M T$ & - & 2,213 \\
\hline 12 & NA & ATG $>$ ATA & 7 & 237 & Met $\rightarrow$ lle & only MT & NA & - & 4,160 \\
\hline 13 & $\mathrm{LOH}$ & GTG>ATG & 6 & 216 & $\mathrm{Val} \rightarrow \mathrm{Met}$ & $M T>W T$ & $\mathrm{WT}=\mathrm{MT}$ & $25-35 \%$ & 2,478 \\
\hline 14 & $\mathrm{LOH}$ & GGC>AGC & 7 & 245 & Gly $\rightarrow$ Ser & $M T=W T$ & WT $>M T$ & $35-45 \%$ & 3,271 \\
\hline 15 & $\mathrm{LOH}$ & $\mathrm{CGC}>\mathrm{CAC}$ & 5 & 175 & $\mathrm{Arg} \rightarrow \mathrm{His}$ & only MT & $\mathrm{WT}=\mathrm{MT}$ & $25-35 \%$ & 4,215 \\
\hline 16 & $\mathrm{LOH}$ & negative & & & & & & $15-25 \%$ & 2,607 \\
\hline 17 & $\mathrm{LOH}$ & negative & & & & & & $25-35 \%$ & 2,932 \\
\hline 18 & $\mathrm{LOH}$ & negative & & & & & & $15-25 \%$ & 2,606 \\
\hline 19 & $\mathrm{LOH}$ & 13372 ins $C$ & 6 & 205 & Frameshift & $\mathrm{WT}=\mathrm{MT}$ & $\mathrm{WT}=\mathrm{MT}$ & $50-60 \%$ & 1,803 \\
\hline 20 & $\mathrm{ROH}$ & negative & & & & & & - & 4,017 \\
\hline 21 & $\mathrm{LOH}$ & negative & & & & & & $15-25 \%$ & 2,981 \\
\hline 22 & $\mathrm{LOH}$ & negative & & & & & & $15-25 \%$ & 1,867 \\
\hline 23 & $\mathrm{LOH}$ & negative & & & & & & $25-35 \%$ & $\mathrm{I}, 482$ \\
\hline
\end{tabular}

$\mathrm{LOH}$, loss of heterozygosity; MT, mutated template; MT>WT, prevalence of mutated template; NA, not analyzed; WT, wild type template; WT = $M T$, equal amount of wild type and mutated template; WT $>M T$, prevalence of wild type template; ROH, retention of heterozygosity; $U$, uninformative (samples I-18, positive immunohistochemistry; samples 19-23, negative immunohistochemistry).

As much as $\mathbf{2 5 \%}$ of mutated template could escape detection during DNA sequencing

The analyses of sequencing sensitivity showed the mutation following enrichment of mutated template by $25 \%$ only in one case (case no. 3 in Table 1) whereas in the second case (patient with Li-Fraumeni syndrome), the mutated template was still difficult to detect. Based on this data, we concluded that the presence of $25 \%$ of mutated template can lead to misinterpretation of sequencing results and may suggest that $25 \%$ of mutated template could be difficult to detect during sequencing of DNA (Figure 1). 


\section{P53 mRNA is overexpressed in the subgroup of colorectal} cancers if compared with normal tissues

P53 mRNA levels were compared among three groups: first, cases with P53 missense mutations; second, cases lacking of a P53 mutation, third, a control group represented by normal colon, brain and renal tissues. The differences in gene expression levels were evaluated by the Mann-Whitney U test. mRNA expression level was significantly higher $(P=0,0022)$ in the group with missense P53 mutation as compared with the group of control tissues. P53 mRNA expression was also significantly higher $(P=0,026)$ in the group of cancers without a $P 53$ mutation as compared with the control group. P53 expression was not significantly different between two groups of cancer samples (Figure 2).

\section{Immunohistochemistry}

18 CC cases showed P53 positive immunoreactivity, while five cases demonstrated no immunoreactivity (Table 1, Figure 3). 15 samples with a high P53 labelling index showed missense mutations, but a single case without P53 immunoreactivity contained a nonsense mutation. P53 mRNA overexpression was observed in samples with both positive and negative P53 immunoreactivity.

\section{Discussion}

We present here an analysis of colorectal cancer that supports our previous data published for glioblastoma, demonstrating that a higher amount of mutated P53 template is detected at the mRNA level than on the DNA level [1]. The approach based on cDNA analysis resulted in an increase of the detection of P53 mutations in CC. Several samples interpreted initially as ambiguous or with no P53 mutation on DNA sequencing, demonstrated mutations following the cDNA analysis. The explanation for this discrepancy could be the contamination of analyzed specimens by cells with the wild type P53, combined with mutated P53 mRNA overexpression, and a phenomenon of P53 heterozygous or hemizygous mutations. Our data supports this explanation. Histopathological examinations and $\mathrm{LOH}$ analysis showed a high content of normal cells in the majority of samples and the presence of hemizygous P53 mutations. Real time RT-PCR analyses confirmed the P53 mRNA overexpression in colorectal cancer cells.

Moreover it should be realized that P53 mutation occurs at last stage of CC tumorigenesis and is not observed in all neoplastic cells. This issue was presented by Goranova et al. and by Giaretti et al. [6,7]. Goranova et al. showed samples presenting: neoplastic cells with P53 mutation, and cells showing APC and/or K-Ras mutation but not P53 mutation [6]. Contamination or enrichment of tumor samples by cells without P53 mutation (normal and/or neoplastic) is obviously causing difficulties in P53 muta- tion detection during colorectal cancer DNA analysis. In addition similar discrepancies between P53 mRNA and DNA analyses for breast cancers were already published by Williams et al. [8].

Heterozygous or hemizygous mutations of P53 have been observed frequently $[9,10]$. Disregard of the latter phenomenon appears questionable in the light of data presented here. If a tumor sample contains $50 \%$ of tumor cells with heterozygous mutation, only $25 \%$ of mutated template can be detected. Similarly, a sample containing a hemizygous mutation will show $33 \%$ of mutated template. We showed here that the mutated template present in the range of $25 \%$ to $30 \%$ could be really difficult to detect during sequencing analysis. Analogous data of the sequencing sensitivity have been already published by Cheng and Haas [11].

Since contamination is certain and mRNA analysis prevails DNA analysis, overexpression of mutated P53 mRNA has to be accepted as logical. Our results showing dominance of mutated template following the cDNA sequencing and an almost complete absence of mutated template following the DNA analysis could not be explained only by the elimination of wild type allele at the mRNA level. In contrast, overexpression of mutated mRNA is suggested by our analysis. However, we still cannot exclude that upregulation of P53 mutated allele coexists with silencing of the wild type allele in colorectal cancer. Overexpression of P53 mRNA occurring both in cancer with and without P53 mutation may result from P53 gene activation by DNA damage, $K$-Ras activation, etc.

It must be stressed that the explanation of discrepancies between the DNA and the CDNA analyses detected in CC cannot be generalized for other cancers. Colorectal cancers most likely carry hemizygous mutations, whereas we have already found that glioblastomas contain mostly heterozygous mutations of P53. Explanatory conditions for discrepancies between direct sequencing of the cDNA and the DNA analyses could be applied without any additional factors only for those cases presenting hemizygous mutations of P53. However, cases presenting the heterozygous mutation require searching for mechanisms responsible for selective overproduction of mutated P53 mRNA only. Nevertheless, from hypotheses presented for glioblastomas, the one suggesting selective overproduction of mutated P53 seems to be most relevant to CC [1].

Our data has also shed new light on the P53 protein accumulation in the context of P53 mutation. A correlation between P53 mutations and the accumulation of P53 in the nucleus has been observed a long time ago $[12,13]$. Furthermore, discrepancies between the immunohistochemical and the DNA molecular analyses, analogous to 
Table 2: Summary of detailed microsatellite analysis performed for chromosome $17 \mathrm{p}$.

\begin{tabular}{|c|c|c|c|c|}
\hline No & $\begin{array}{c}\text { DI7SI828 } \\
\text { (3.700 kbp) }\end{array}$ & $\begin{array}{c}\text { DI7S675 } \\
\text { (4.403 kbp) }\end{array}$ & $\begin{array}{c}\text { DI7S729 } \\
\text { (7.156 kbp) }\end{array}$ & $\begin{array}{c}\text { DI7S976 } \\
\text { (17.858 kbp) }\end{array}$ \\
\hline I & $\mathrm{ROH}$ & LOH & LOH & LOH \\
\hline 2 & LOH & $\mathrm{NI}$ & $\mathrm{NI}$ & LOH \\
\hline 3 & $\mathrm{ROH}$ & $\mathrm{ROH}$ & LOH & $\mathrm{NI}$ \\
\hline 4 & LOH & $\mathrm{NI}$ & $\mathrm{NI}$ & $\mathrm{NI}$ \\
\hline 5 & LOH & $\mathrm{NI}$ & $\mathrm{NI}$ & LOH \\
\hline 6 & LOH & LOH & LOH & $\mathrm{NI}$ \\
\hline 7 & $\mathrm{NI}$ & $\mathrm{NI}$ & $\mathrm{NI}$ & $\mathrm{NI}$ \\
\hline 8 & $\mathrm{ROH}$ & $\mathrm{ROH}$ & $\mathrm{ROH}$ & $\mathrm{ROH}$ \\
\hline 9 & $\mathrm{ROH}$ & $\mathrm{NI}$ & $\mathrm{NI}$ & $\mathrm{ROH}$ \\
\hline 10 & LOH & LOH & $\mathrm{NI}$ & LOH \\
\hline II & $\mathrm{ROH}$ & $\mathrm{NI}$ & $\mathrm{NI}$ & $\mathrm{ROH}$ \\
\hline 12 & NA & NA & NA & NA \\
\hline 13 & LOH & LOH & $\mathrm{NI}$ & LOH \\
\hline 14 & LOH & $\mathrm{NI}$ & LOH & LOH \\
\hline 15 & $\mathrm{NI}$ & LOH & $\mathrm{NI}$ & LOH \\
\hline 16 & LOH & $\mathrm{NI}$ & $\mathrm{NI}$ & LOH \\
\hline 17 & LOH & LOH & $\mathrm{NI}$ & LOH \\
\hline 18 & $\mathrm{ROH}$ & $\mathrm{ROH}$ & LOH & LOH \\
\hline 19 & LOH & LOH & $\mathrm{NI}$ & LOH \\
\hline 20 & $\mathrm{ROH}$ & $\mathrm{ROH}$ & $\mathrm{NI}$ & $\mathrm{ROH}$ \\
\hline 21 & LOH & $\mathrm{NI}$ & $\mathrm{NI}$ & LOH \\
\hline 22 & LOH & $\mathrm{NI}$ & $\mathrm{NI}$ & LOH \\
\hline 23 & LOH & $\mathrm{ROH}$ & $\mathrm{NI}$ & LOH \\
\hline
\end{tabular}

$\mathrm{LOH}$, loss of heterozygosity; NA, not analyzed; NI, non informative; $\mathrm{ROH}$, retention of heterozygosity. Numbers in brackets indicate the distance from the centromere (kbp) determined according to HuRef Database. P53 (7.169 kbp) gene is located between DI7S729 and DI7S976.

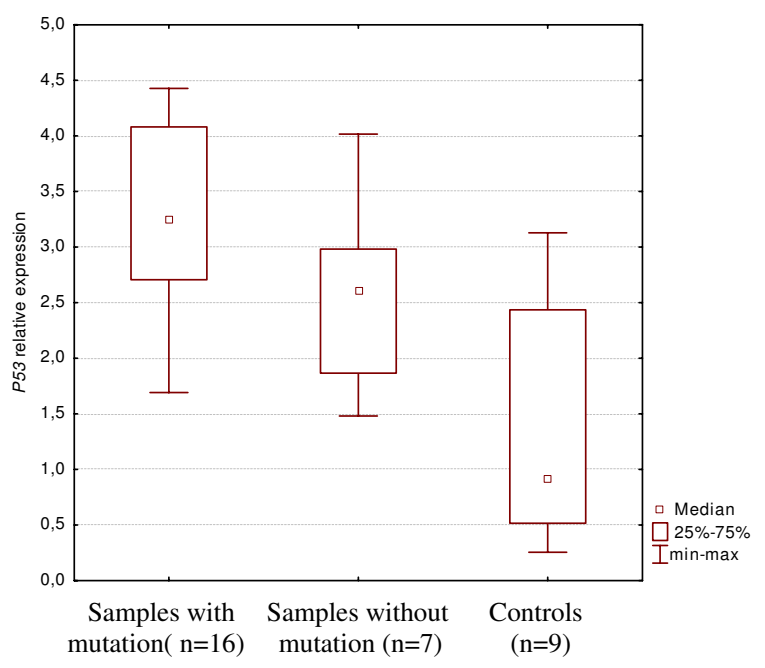

Figure 2

P53 expression level in tumor samples with mutation and tumor samples without mutation versus control tissue. Significance of difference according to Mann-Whitney $U$ test, $P<0.05$.

those observed by us, have also been presented many times. They were always attributed to the decreasing value of immunohistochemistry [14-16]. Our data based on the sequencing of both DNA and cDNA and, in addition, immunohistochemistry did not suggest that the DNA molecular analysis is always more robust to detect P53 mutation in CC. We suggest that cellular heterogeneity could at least partially explain, the discrepancies observed during the P53 immunohistochemical analysis and the P53 DNA sequencing in favor of immunohistochemistry. However one should be aware of the fact that already published correlations and discrepancies between P53 accumulation and P53 mutations, were analyzed in many experimental conditions. SSCP (single strand conformation polimorphism) analysis, DHPLC (denaturing high performance liquid chromatography) technique, direct DNA sequencing, presence of missense and nonsense mutaitons, etc. All these factors biase interpetation of data, dedicated to compare immunohistochemical and molecular analysis of P53/P53. We do not intend to oversimplify the very complex issue of correlations between immunohistochemical and molecular analysis. Nevertheless our new approach based on the cDNA analysis increases P53 mutation detectability and allows to decrease the number of CC cases presenting abundant P53 nuclear accumulation but lacking the P53 mutation. Our data suggests that P53 mutations detection in colorectal cancer can be improved. We are aware that techniques such as DHPLC allowing to collect the mutant 

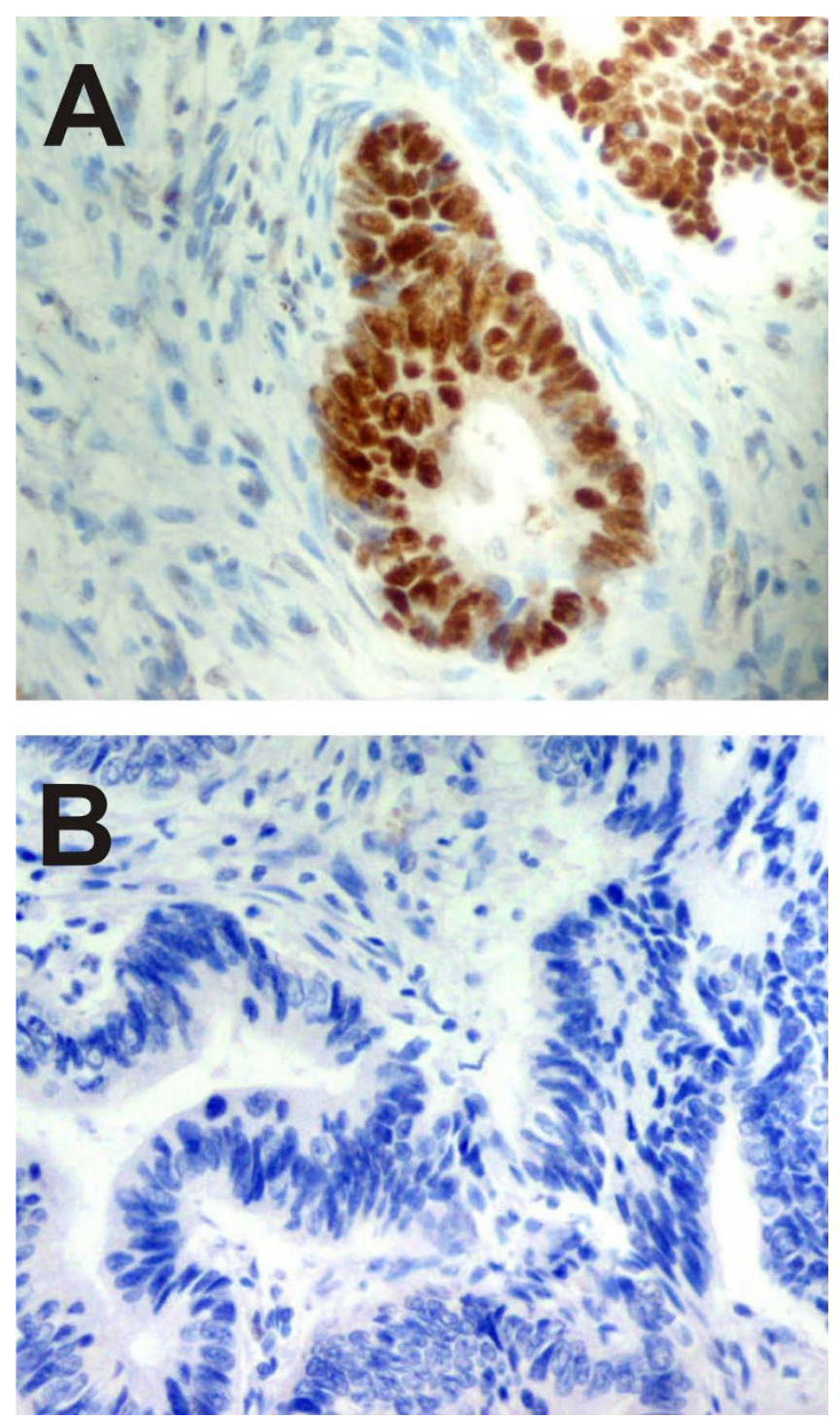

Figure 3

P53 immunohistochemistry. (A) case no. 2 with nuclear expression of the protein. (B) case no. 20 without immunopositivity for P53. Magnification 200x.

peaks by means of fraction collection increases sensitivity of the nucleic acid mutation detection. However it should be remembered that this technique although very sensitive, in terms of the percentage of mutated template detected, does not allow to detect all kinds of mutations [17-20]. To this end we recomend to increase sensitivity of missense mutations detection by direct CDNA sequencing. P53 cDNA DHPLC followed by sequencing of collected mutated template should also be considered. Detection of nonsense mutations has to be done by DNA analysis, since decay of nonsense mutated mRNA, will negatively influence sensitivity of cDNA analysis.

We would like to add that the observed overexpression of P53 mRNA in colorectal cancer cells does not seem to be responsible for $\mathrm{P} 53$ protein accumulation. Almost all CC samples showed the P53 mRNA overexpression, including samples with no P53 nuclear accumulation.

\section{Conclusion}

The most important findings of this study are as follows: 1 , cDNA sequencing appears superior to DNA sequencing in detecting P53 missense mutations in colorectal cancer; 2 , colorectal cancer demonstrates overexpression of mutated P53 mRNA; 3, positive P53 immunoreactivity in CC, along with negative results for P53 DNA sequencing, should not be so readily discarded in favor of the results of DNA analysis $[16,21]$. We suggest that the P53 cDNA sequencing should be applied for all cancers, since P53 mRNA analysis can increase mutation detectability.

\section{Competing interests}

The authors declare that they have no competing interests.

\section{Authors' contributions}

MS, MZ and PR designed project and performed sequencing and MSI analyses. PR and PPL was responsible for supervising and founding acquisition. DKW and IZ performed LOH analyses. RK, GPW and DJK participated in providing samples for experiments and in obtaining immunohistochemical data. RS performed Real-time PCR and statistical analysis. All authors participated in analysis and interpretation of obtained data. All authors have been involved in drafting the manuscript. All authors have given approval of the final version of the manuscript.

\section{Acknowledgements}

Prof. James W. Ironside, National CJD Surveillance Unit, Edinburgh, Scotland is kindly acknowledged for helpful criticism. This work was supported by Minister of Science and Higher Education Grants No. N N 40I 020635 and N N 40 I 155833 I558 and Medical University grant No. 502-I I-857.

\section{References}

I. Szybka M, Zawlik I, Kulczycka D, Golanska E, Jesien E, Kupnicka D, Stawski R, Piaskowski S, Bieniek E, Zakrzewska M, Kordek R, Liberski $\mathrm{PP}$, Rieske P: Elimination of wild-type P53 mRNA in glioblastomas showing heterozygous mutations of P53. Br J Cancer 2008, 98: $|43|-3$.

2. Zakrzewska M, Wojcik I, Zakrzewski K, Polis L, Grajkowska W, Roszkowski M, Augelli B], Liberski PP, Rieske P: Mutational analysis of hSNF5/INII and P53 genes in choroid plexus carcinomas. Cancer Genet Cytogenet 2005, 156: 179-82.

3. Rieske P, Zakrzewska M, Biernat W, Bartkowiak J, Zimmermann A, Liberski PP: Atypical molecular background of glioblastoma and meningioma developed in a patient with $\mathrm{Li}$-Fraumeni syndrome. J Neurooncol 2005, 7 I:27-30. 
4. Pfaffl MW, Horgan GW, Dempfle L: Relative expression software tool (REST) for group-wise comparison and statistical analysis of relative expression results in real-time PCR. Nucleic Acids Res 2002, 30:e36.

5. Wozniak K, Piaskowski S, Gresner SM, Golanska E, Bieniek E, Bigoszewska K, Sikorska B, Szybka M, Kulczycka-Wojdala D, Zakrzewska M, Zawlik I, Papierz W, Stawski R, Jaskolski DJ, Och W, Sieruta $M$, Liberski PP, Rieske P: BCR expression is decreased in meningiomas showing loss of heterozygosity of $22 q$ within a new minimal deletion region. Cancer Genet Cytogenet 2008, 183: 14-20.

6. Goranova TE, Ohue M, Kato K: Putative precursor cancer cells in human colorectal cancer tissue. Int J Clin Exp Pathol 2009, 2:154-62.

7. Giaretti W, Rapallo A, Sciutto A, Macciocu B, Geido E, Hermsen MA, Postma C, Baak JP, Williams RA, Meijer GA: Intratumor heterogeneity of k-ras and p53 mutations among human colorectal adenomas containing early cancer. Anal Cell Pathol 2000, 21:49-57.

8. Williams C, Norberg T, Ahmadian A, Pontén F, Bergh J, Inganäs M, Lundeberg J, Uhlén M: Assessment of sequence-based p53 gene analysis in human breast cancer: messenger RNA in comparison with genomic DNA targets. Clin Chem 1998, 44:455-62.

9. Chan WM, Siu WY, Lau A, Poon RY: How many mutant p53 molecules are needed to inactivate a tetramer? Mol Cell Biol 2004, 24:3536-355I.

10. Dittmer D, Pati S, Zambetti G, Chu S, Teresky AK, Moore M, Finlay C, Levine AJ: Gain of function mutations in p53. Nat Genet 1993, 4:42-46.

II. Cheng J, Haas M: Sensitivity of detection of heterozygous point mutations in p53 cDNAs by direct PCR sequencing. $P C R$ Methods Appl 1992, I:199.

12. Bodner SM, Minna JD, Jensen SM, D'Amico D, Carbone D, Mitsudomi T, Fedorko J, Buchhagen DL, Nau MM, Gazdar AF: Expression of mutant p53 proteins in lung cancer correlates with the class of p53 mutation. Oncogene 1992, 7:743-749.

13. Soong R, Robbins PD, Dix BR, Grieu F, Lim B, Knowles S, Williams KE, Turbett GR, House AK, lacopetta BJ: Concordance between p53 protein overexpression and gene mutation in a large series of common human carcinomas. Hum Pathol 1996, 27:1050-1055

14. Hall PA, Lane DP: p53 in tumour pathology: can we trust immunohistochemistry? R revisited! J Pathol 1994, 172: I-4.

15. Hurlimann J, Chaubert $P$, Benhattar J: p53 gene alterations and p53 protein accumulation in infilltrating ductal breast carcinomas: correlation between immunohistochemical and molecular biology techniques. Mod Pathol 1994, 7:423-428.

16. Calzolari A, Chiarelli I, Bianchi S, Messerini L, Gallo O, Porfirio B, Mattiuz PL: Immunohistochemical vs. molecular biology methods: complementary techniques for effective screening of p53 alterations in head and neck cancer. Am J Clin Pathol 1997, 107:7-II.

17. Holinski-Feder E, Müller-Koch Y, Friedl W, Moeslein G, Keller G, Plaschke J, Ballhausen W, Gross M, Baldwin-Jedele K, Jungck M, Mangold E, Vogelsang H, Schackert HK, Lohsea P, Murken J, Meitinger T: DHPLC mutation analysis of the hereditary nonpolyposis colon cancer (HNPCC) genes hMLHI and hMSH2. J Biochem Biophys Methods 200I, 47:21-32.

18. Singer G, Stöhr R, Cope L, Dehari R, Hartmann A, Cao DF, Wang TL, Kurman RJ, Shih leM: Patterns of $\mathrm{p} 53$ mutations separate ovarian serous borderline tumors and low- and high-grade carcinomas and provide support for a new model of ovarian carcinogenesis: a mutational analysis with immunohistochemical correlation. Am J Surg Pathol 2005, 29:2 18-24.

19. Pan ZZ, Wan DS, Chen G, Li LR, Lu ZH, Huang B]: Co-mutation of $p 53$, K-ras genes and accumulation of $\mathrm{p} 53$ protein and its correlation to clinicopathological features in rectal cancer. World J Gastroenterol 2004, 10:3688-90.

20. Curtin K, Slattery ML, Holubkov R, Edwards S, Holden JA, Samowitz WS: $\mathbf{5 3}$ alterations in colon tumors: a comparison of SSCPI sequencing and immunohistochemistry. Appl Immunohistochem Mol Morphol 2004, I 2:380-6.

21. Soong R, Robbins PD, Dix BR, Grieu F, Lim B, Knowles S, Williams $\mathrm{KE}$, Turbett GR, House AK, lacopetta BJ: Concordance between p53 protein overexpression and gene mutation in a large series of common human carcinomas. Hum Pathol 1996, 27:1050-1055.

\section{Pre-publication history}

The pre-publication history for this paper can be accessed here:

http://www.biomedcentral.com/1471-2407/9/278/pre pub
Publish with Bio Med Central and every scientist can read your work free of charge

"BioMed Central will be the most significant development for disseminating the results of biomedical research in our lifetime. "

Sir Paul Nurse, Cancer Research UK

Your research papers will be:

- available free of charge to the entire biomedical community

- peer reviewed and published immediately upon acceptance

- cited in PubMed and archived on PubMed Central

- yours - you keep the copyright

Submit your manuscript here:

http://www.biomedcentral.com/info/publishing_adv.asp
BioMedcentral 